\title{
Evaluation of Probiotic Properties of Pediococcus acidilactici B14 in Association with Lactobacillus acidophilus ATCC 4356 for Application in a Soy Based Aerated Symbiotic Dessert
}

\author{
Maria Carolina de Oliveira Ribeiro ${ }^{1,2}$, Luciana Porto de Souza Vandenberghe ${ }^{1 *}$, Michele \\ Rigon Spier $^{1}$, Katia Sabrina Paludo ${ }^{3}$, Carlos Ricardo Soccol ${ }^{1}$ and Vanete Thomaz Soccol ${ }^{1}$ \\ ${ }^{I}$ Departamento de Engenharia de Bioprocessos e Biotecnologia; Universidade Federal do Paraná; Curitiba - PR - \\ Brasil. ${ }^{2}$ Departamento de Alimentos; Universidade Tecnológica Federal do Paraná; Ponta Grossa- PR-Brasil. \\ ${ }^{3}$ Departamento de Biologia Estrutural, Molecular e Genética; Universidade Estadual de Ponta Grossa; Ponta \\ Grossa - PR - Brasil
}

\begin{abstract}
The aim of this study was to evaluate the probiotic properties of Pediococcus acidilactici B14 and to study its resistance in the gastrointestinal system when combined with Lactobacillus acidophilus ATCC 4356 and used in a potentially symbiotic aerated soy based dessert. P. acidilactici $B 14$ showed some important probiotic characteristics such as survival rate of $45.9 \%$ at $\mathrm{pH} 2.5 ; 72.4 \%$ in $0.3 \%$ bile salts and $95.8 \%$ after gastrointestinal transit at $\mathrm{pH}$ 4.0. Tolerance against the antibiotics cephalexin, neomycin, vancomycin, cefotaxime and penicillin $G$ was also observed. The strain inhibited antagonism against the following cultures: Escherichia coli ATCC 25922, Bacillus cereus ATCC 33018, Staphylococcus aureus ATCC 6538P and Salmonella sp. The mixed culture of P. acidilactici B14 with L. acidophilus ATCC 4356 showed a survival rate of $92.4 \%$ after the passage through the gastrointestinal system at pH 4.0. Furthermore, in the presence of the food matrix, an average increase in cell viability, after being subjected to the gastrointestinal system of $9.9 \%$ at $\mathrm{pH} 2.0$ and $6.1 \%$ at $\mathrm{pH} 4.0$, was observed. This characterized the adequacy of the associated culture as probiotic in the development of a functional food such as soy based aerated symbiotic dessert.
\end{abstract}

Key words: Pediococcus acidilactici, Lactobacillus acidophilus, gastrointestinal system, probiotics, soy

\section{INTRODUCTION}

Probiotics are beneficial microorganisms that may affect the health of the host by improving the intestinal microbial balance and/or by their action on metabolic activities of indigenous flora (Darilmaz et al. 2011).

Characteristics such as total security for the host, resistance to gastric acidity and pancreatic secretions, adhesion to intestinal epithelial cells, antimicrobial activity, inhibition of the adhesion of pathogenic bacteria, antibiotic resistance, tolerance to food additives and stability in the food matrix, are all considered relevant in tracing the probiotic profile of a specific strain (Soccol et al. 2010). Pediococci are used as beneficial microorganisms in the context of food and livestock microbiology (Haakensen et al. 2009) and can be used as starter cultures or as probiotics (Klare et al. 2007). P. acidilactici has interesting

*Author for correspondence: lucianapsv@gmail.com 
properties, such as resistance to heat, cold, $\mathrm{pH}$, proteolytic treatments, and the capacity for the production of antimicrobial peptide (pediocin) with anti-listerial activity and antimicrobial spectrum, which makes it interesting as a food biopreservative (Papagianni and Anastasiadou 2009). Lb. acidophilus ATCC 4356 possesses probiotic potential, such as action in cholesterol metabolism (Huang and Zheng 2010) and antagonistic activity against the $C$. jejuni pathogen (Campana et al. 2012), among others.

The food matrix has been a topic of current research in the probiotic field because it can influence functionality (Vinderola et al. 2012). The presence of food and some food ingredients improves the viability of microorganisms during gastric transit; the proposed mechanism for this beneficial effect is probably linked to the increase of the $\mathrm{pH}$ of the gastric content (MonteagudoMera et al. 2012). The study of the tolerance to gastrointestinal conditions, conducted with probiotic bacteria incorporated in the final product, is useful when selecting a suitable food matrix, which contributes to their survival in this environment (Buriti et al. 2010).

This study aimed to evaluate the probiotic properties of $P$. acidilactici B14 and to study its resistance to the gastrointestinal system when associated with $L b$. acidophilus ATCC 4356 and implemented in an aerated dessert with potentially symbiotic characteristics, with soy as food matrix.

\section{MATERIALS AND METHODS}

\section{Bacterial Strains}

The P. acidilacti B14 and Lb. acidophilus ATCC 4356 strains were obtained from the culture bank of the Bioprocess Engineering and Biotechnology Division of the Federal University of Paraná (UFPR, Curitiba, Brazil). The Salmonella sp., B. cereus ATCC 33018, S. aureus ATCC 6538P and $E$. coli ATCC 2592 pathogenic strains were obtained from the Department of Food of the Federal Technological University of Paraná (UTFPR, Ponta Grossa, Brazil). The HRT-18 (ATCC CCL-244) cell strain, from the human colon, was obtained from the cell bank of the Department of Cell Biology and Molecular Genetics of the State University of Ponta Grossa (UEPG, Ponta Grossa, Brazil).

\section{Food Ingredients}

The production of the symbiotic aerated soy dessert was carried out with the following commercial standard food ingredients: soy extract powder (Jasmine, Curitiba, Brazil); whole pasteurised pulp and frozen passion fruit (De Marchi, Jundiaí, Brazil), milk cream (20.0\% fat, Líder, Lobato, Brazil), sucrose (Coopersucar União, Limeira, Brazil), skimmed milk powder (Sancor, Santa Fé, Argentina), inulin (Orafti HPX, Beneo-Orafti, Oreye, Belgium), oligofructose (Orafti P95, Beneo-Orafti), emulsifier (Duas Rodas, Jaraguá do Sul, Brazil), colourless gelatine powder (Dr. Oetker, São Paulo, Brazil), corn glucose syrup, (Yoki, Paranavaí, Brazil ), whey protein concentrate $(80.0 \%$ protein, Alibra, Marechal Cândido Rondom, Brazil) and potassium sorbate (Biotec, Pinhais, Brazil).

\section{Recovery and Maintenance of Strains}

The strains were maintained in $20 \%$ of sterile glycerol (Biotec) at $-80 \pm 1^{\circ} \mathrm{C}$. They were initially retrieved by three successive reactivation steps in $1.0 \%$ of Man, Rogosa and Sharpe (MRS) broth (Himedia, Mumbai, India) at $37 \pm 1^{\circ} \mathrm{C}$ for $16 \mathrm{~h}$ and, subsequently, kept at $4 \pm 1{ }^{\circ} \mathrm{C}$. Cultures were reactivated in a cell suspension at a rate of $1.0 \%$ $(\mathrm{v} / \mathrm{v})$ in MRS broth at $37 \pm 1^{\circ} \mathrm{C}$ for $16 \mathrm{~h}$.

\section{Characterisation of the Probiotic Potential of $P$. acidilactici B14}

Evaluation of Pathogenicity Factors

The hemolytic activity, adapted from Baumgartner et al. (1998), was determined in Brain Heart Infusion (BHI) agar (Himedia) supplemented with $5.0 \%$ of defibrinated sheep blood (New Prov, Pinhais, Brazil) at $37 \pm 1{ }^{\circ} \mathrm{C}$ for $48 \mathrm{~h}$. The formation of zones was identified as of potential hemolysis. The production of gelatinase was evaluated in nutrient agar (Himedia) supplemented with $3.0 \%$ gelatine (Oxoid, Basingstoke, England) at $21 \pm 1^{\circ} \mathrm{C}$ for seven days and $4 \pm 1^{\circ} \mathrm{C}$ for $30 \mathrm{~min}$. The liquefaction of the gelatine after cooling indicated a positive result of the reaction ( $\mathrm{Su}$ et al. 1991). The production of lipolytic enzymes, adapted from Albano et al. (2009), was determined in BHI agar supplemented with $0.2 \%$ of sodium chloride (Biotec), 1.0\% of Tween-80 (Merck, Darmstadt, Germany) and $0.005 \%$ of bromocresol green (Vetec, Rio de Janeiro, Brazil) at $37 \pm 1^{\circ} \mathrm{C}$ for $48 \mathrm{~h}$. The formation of clear zones around the colonies indicated a positive reaction. 


\section{Production of Lactic Acid}

The configuration and quantification of the isomers of lactic acid produced from glucose were determined enzymatically in the supernatant, after the separation of cells, using D-lactate dehydrogenase (D-LDH) and L-lactate dehydrogenase (L-LDH) from an Enzyplus kit (Diffchamb, Vastra Frolunda, Sweden).

\section{Resistance to Acidic $\mathrm{pH}$ and Bile Salts}

The behaviour of the cell strain in relation to acidic $\mathrm{pH}$ and the presence of bile salts were evaluated according to Tulini et al. (2013). The resistance to variation in $\mathrm{pH}$ was evaluated by the analysis of the resultant cell viability during 180

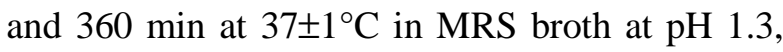
2.5 and 4.0, adjusted with concentrated hydrochloric acid (Vetec). MRS broth at $\mathrm{pH} 6.5$ was used as control. The tolerance to bile salts was determined by the resulting cell viability after 180 and $360 \mathrm{~min}$ at $37 \pm 1^{\circ} \mathrm{C}$ in MRS broth supplemented with $0.3 \%$ and $1.0 \%$ of bovine bile salts (Deg, São Paulo, Brazil). MRS broth without supplementation was used as control. The microbiological method used for determining the cell viability was the drop plate method (Da Silva et al. 2010).

\section{Resistance to Antibiotics}

The resistance of the strain to antibiotics was determined by the disc diffusion method (Clinical and Laboratory Standards Institute 2003). Antibiotics with different mechanisms of action were used, such as cell wall inhibitors, which were $\beta$-lactam from the penicillin group (amoxicillin and penicillin G); $\beta$-lactam cephalosporinics (cephalexin and cefotaxime); $\beta$-lactam carbapenems (imipenem) and glycopeptides (vancomycin). Protein synthesis inhibitors such as tetracyclines (tetracycline), aminoglycosides (neomycin), phenolics (chloramphenicol), lincosamides (clindamycin) and macrolides (erythromycin) (New Prov) were used. The diameter $(\mathrm{mm})$ of inhibition zones around the discs was measured.

\section{Behaviour in Relation to Pathogens}

The evaluation of the performance of the strain in relation to pathogens was conducted using the spot-on-lawn method (Ahmadova et al. 2013). The diameter $(\mathrm{mm})$ of inhibition zones around the aliquots of the strain was measured.

\section{Adhesion Capacity}

The standard of adhesion of the strain was determined using cells of the human colon HRT18 (ATCC CCL-244). The cells were cultivated in culture flasks with baffles containing RPMI-1640 culture medium (Cultilab, São Paulo, Brazil) with $10.0 \%$ foetal bovine serum (Gibco, Carlsbald, USA), $0.001 \%$ of streptomycin (Cultilab) and 10,000 IU/L penicillin (Cultilab), kept under an atmosphere of $5.0 \%$ of carbon dioxide at $37 \pm 1{ }^{\circ} \mathrm{C}$ after washing with trypsin (Sigma-Aldrich, St. Louis, USA). The cells were added at a concentration of $2 \times 10^{4} /$ well in microplates (TPP, St. Louis, USA) containing sterile glass coverslips, and incubated at $37 \pm 1{ }^{\circ} \mathrm{C}$ under an atmosphere of $5.0 \%$ of carbon dioxide for $48 \mathrm{~h}$. To assess the adhesion, the cells were washed twice with sterile PBS (pH 7.4) composed of $0.8 \%$ sodium chloride, $0.07 \%$ anhydrous disodium phosphate (Biotec) and $0.02 \%$ of monopotassium phosphate (Biotec), and once with RPMI-1640. Then, $0.4 \mathrm{~mL}$ of RPMI with $10.0 \%$ foetal bovine serum and $0.1 \mathrm{~mL}$ of bacterial suspension $\left(10^{7}-10^{8}\right.$ $\mathrm{UFC} / \mathrm{mL}$ ) were added to the cellular culture. After $75 \mathrm{~min}$ at $37 \pm 1^{\circ} \mathrm{C}$, the cultures were washed four times with sterile PBS, fixed with $2.0 \%$ solution of formaldehyde (Sigma-Aldrich) for $2 \mathrm{~min}$, and subjected to May-Grünwald-Giemsa staining. After staining, the coverslips were rinsed in distilled water, mounted, sealed and examined by light microscopy.

\section{Resistance to the Gastrointestinal System}

The in vitro simulation of the resistance of bacteria to the gastrointestinal system (GIS), represented by the cell viability, was adapted from Fernández et al. (2003). The simulated gastric juice (GJ) consisted of a solution composed of $125.0 \mathrm{~mm}$ sodium chloride, $7.0 \mathrm{~mm}$ potassium chloride (Biotec), $45.0 \mathrm{~mm}$ sodium bicarbonate and $3.0 \%$ of porcine pepsin (Nuclear, Diadema, Brazil). The GJ was used in $\mathrm{pH} 2.0$ and 4.0, adjusted with concentrated hydrochloric acid and sterilised in a $0.45 \mu \mathrm{m}$ porosity filter (Sartorius Stedim Biotech, Bohemia, USA). The simulated intestinal juice (IJ) was formulated with $0.5 \%$ of sodium chloride, $0.1 \%$ porcine pancreatin $(350$ FIP-U/g protease; 6000 FIP-U/g lipase, 7500 FIPU/g amylase - Merck), $0.15 \%$ of bovine bile (Himedia) at $\mathrm{pH} 8.0$, adjusted with $5.0 \mathrm{M}$ solution of sodium hydroxide, then sterilised by microfiltration at $0.45 \mu \mathrm{m}$ porosity. The resistance of the culture was evaluated at $\mathrm{pH} 2.0$ and 4.0 for 
the GJ at the intervals of $90 \mathrm{~min}\left(\mathrm{~T}_{1}\right)$ and $180 \mathrm{~min}$ $\left(\mathrm{T}_{2}\right)$, and at $\mathrm{pH} 8.0$ for the $\mathrm{IJ}$ at times of $270 \mathrm{~min}$ $\left(\mathrm{T}_{3}\right)$ and $360 \mathrm{~min}\left(\mathrm{~T}_{4}\right)$.

The bacterial cell suspension was centrifuged (3087xg for $10 \mathrm{~min}$ ) and the biomass pellet was washed twice and reconstituted with sterile saline to original volume. The reconstituted biomass was diluted in peptone water for growth control $\left(\mathrm{T}_{0}\right)$, plated in MRS agar by the drop plate method, and incubated at $37 \pm 1^{\circ} \mathrm{C}$ for $48 \mathrm{~h}$. From the reconstituted material, four aliquots of $1.0 \mathrm{~mL}$ were collected and added into tubes containing 9.0 $\mathrm{mL}$ of GJ at $\mathrm{pH} 2.0$ and $\mathrm{pH} 4.0$ and incubated at $37 \pm 1^{\circ} \mathrm{C}$ and $150 \mathrm{rpm}$. After 90 and $180 \mathrm{~min}$ of incubation, respectively, the tests $T_{1}$ and $T_{2}$ were removed, diluted and plated. From the cellular content of the $\mathrm{T}_{2}$ assay, $1.0 \mathrm{~mL}$ aliquots of the GJ at $\mathrm{pH} 2.0$ and $\mathrm{pH} 4.0$ were collected after stirring and added to $9.0 \mathrm{~mL}$ tubes of $\mathrm{IJ}(\mathrm{pH} 8.0)$. These were maintained at $37 \pm 1^{\circ} \mathrm{C}$ and $150 \mathrm{rpm}$ for a further 90 and $180 \mathrm{~min}$ of incubation and then diluted and plated. Tests $\mathrm{T}_{3}$ and $\mathrm{T}_{4}$ were also conducted, totalling $270 \mathrm{~min}$ and $360 \mathrm{~min}$, respectively.

\section{Development of the Associated Culture}

The association between $P$. acidilactici B14 and Lb. acidophilus ATCC 4356 was performed with the objective of enhancing the probiotic properties of interest. The main criterion to be evaluated was resistance to the drastic conditions of the gastrointestinal system. Both the cultures were cultivated separately in MRS broth, as previously described, and they were mixed in a 1:1 ratio at the time of use. The mixed culture was subjected to the same protocol used to evaluate the resistance of $P$. acidilactici $\mathrm{B} 14$ to the GIS, except for the incubation time to determine the cell viability, which was $72 \mathrm{~h}$, due to indications in the literature for the growth of the Lb. acidophilus species.

\section{Development of the Aerated, Potentially Symbiotic Soy Dessert \\ Preparation of the Mixed Culture}

The lactic culture used directly in the dessert was obtained from the aqueous extract of soy, free of chemical additives, produced in the Food Production Unit of the Municipality of Ponta Grossa (Brazil), supplemented with $0.5 \%$ glucose (Merck) and sterilized at $121 \pm 1^{\circ} \mathrm{C}$ for $5 \mathrm{~min}$. After cooling at room temperature $\left(\sim 22^{\circ} \mathrm{C}\right)$, the mixed culture was added at $5.0 \%$ (cell population of $10^{12}-10^{10} \mathrm{UFC} / \mathrm{mL}$ ) and then incubated at $37 \pm 1^{\circ} \mathrm{C}$ for $24 \mathrm{~h}$.

\section{Preparation of the Aerated, Potentially Symbiotic Soy Dessert}

The process of preparing the aerated, potentially symbiotic dessert consisted of the initial mixture of aqueous extract of soy prepared at $6.2 \%$ protein (33.5\%); milk cream (18.5\%); sucrose (11.0\%); skimmed milk powder (3.4\%); inulin (2.5\%); oligofructose (2.5\%); emulsifier $\quad(2.0 \%)$; colourless gelatin powder $(25.1 \%)$; corn syrup $(1.25 \%)$ and whey protein concentrate (1.0\%). After homogenising for $5 \mathrm{~min}$ in a domestic mixer (Black \& Decker, SB 40, Brazil), the mixture was kept for $24 \mathrm{~h}$ at $4 \pm 1^{\circ} \mathrm{C}$ for maximum hydration of solids, followed by pasteurisation at $63-65^{\circ} \mathrm{C} / 30$ $\min$ and cooled to $40 \pm 1^{\circ} \mathrm{C}$. Subsequently, the mixed lactic culture, frozen pasteurized whole pulp of passion fruit, emulsifier and potassium sorbate were added. This was aerated using a domestic mixer (Arno, Planetária, Brazil) for 8 $\mathrm{min}$, filled $40 \mathrm{~g}$ manually in polypropylene containers (PP) of $100 \mathrm{~mL}$ and stored at $4 \pm 1^{\circ} \mathrm{C}$.

Resistance of the Mixed Culture to the Gastrointestinal System in the Food Matrix

Samples of dessert stored for 1, 7, 14, 21 and 28 days were used to assess the resistance of the mixed culture inserted in the food matrix by GIS. The resistance to simulated GIS conditions, obtained by the cell viability of the mixed culture was evaluated using the protocol proposed by Fernández et al. (2003). The composition of GJ and $\mathrm{IJ}$ was similar to the protocol used to evaluate the resistance of $P$. acidilactici B14 to GIS.

A $25 \mathrm{~g}$ portion of the dessert was diluted in 225 $\mathrm{mL}$ of peptone water and homogenized for $1 \mathrm{~min}$. The control $\left(\mathrm{T}_{0}\right)$ was obtained by diluting a sample of the freshly homogenized dessert in peptone water, followed by plating on MRS agar using the drop plate method and incubated at $37 \pm 1^{\circ} \mathrm{C}$ for $72 \mathrm{~h}$. From the homogenized sample, four aliquots of $1.0 \mathrm{~mL}$ were collected and added into tubes containing $9.0 \mathrm{~mL}$ of $\mathrm{GJ}$ at $\mathrm{pH} 2.0$ and $\mathrm{pH} 4.0$ and incubated at $37 \pm 1^{\circ} \mathrm{C}$ at $150 \mathrm{rpm}$. After 90 and $180 \mathrm{~min}$ of incubation, respectively, the tests $\mathrm{T}_{1}$ and $\mathrm{T}_{2}$ were removed, diluted and plated. From the cellular content of the $\mathrm{T}_{2}$ assay, $1.0 \mathrm{~mL}$ aliquots of the GJ at $\mathrm{pH} 2.0$ and $\mathrm{pH} 4.0$ were collected after stirring and added to $9.0 \mathrm{~mL}$ tubes of IJ ( $\mathrm{pH} 8.0$ ). These were maintained at $37 \pm 1^{\circ} \mathrm{C}$ 
and $150 \mathrm{rpm}$ for a further 90 and $180 \mathrm{~min}$ of incubation, then diluted and plated. Tests $T_{3}$ and $\mathrm{T}_{4}$ were also conducted, totalling $270 \mathrm{~min}$ and 360 min, respectively.

\section{Statistical Analysis}

The experimental data were expressed by the mean of triplicates and the respective standard deviation. Differences between the treatments were evaluated by the analysis of variance (ANOVA) using Tukey's post-test, with an error of $\mathrm{p}<0.05$. The SASM-Agri programme version 8.2 was used (Carvalho et al. 2013).

\section{RESULTS AND DISCUSSION}

\section{Characterisation of Probiotic Potential of $P$. acidilactici B14}

Substances produced by the microorganisms that can cause harm to the host are referred to as pathogenicity factors. This term has now come to express any component of a microorganism that is required to generate an illness or enhance it (Araújo and Ferreira 2013). P. acidilactici B14 showed a negative response in the production of gelatinase and lipase enzymes as pathogenicity factors. In terms of the formation of hemolysin, $\gamma$ hemolytic activity was observed, which represented the absence of the production of this enzyme by the strain. $P$. acidilactici B14 was a homo-fermentative culture for lactic aicd production (results not shown), which synthesised in the racemic form of D-(-) lactic acid (0.9\%) and $\mathrm{L}-(+)$ lactic acid $(1.1 \%)$, corresponding to a $\mathrm{L}: \mathrm{D}$ ratio of (1.4:1.0). The culture showed resistance to different $\mathrm{pH}$ conditions, showing viability during
180 min with a significant difference $(\mathrm{p}<0.05)$. A reduction of 51.9, 29.1 and $11.4 \%$ was observed in viability, in comparison to the control $(\mathrm{pH} 6.5)$ at $\mathrm{pH} 1.3,2.5$ and 4.0, respectively.

When a microorganism is exposed to acidic conditions, the $\mathrm{pH}$ homeostasis is maintained by a discharge of $\mathrm{H}^{+}$from the cell, and this process is dependent on the activity of $\mathrm{H}^{+}$-ATPase, which is the enzyme responsible for maintaining the concentration of $\mathrm{H}^{+}$between the cell and the medium. The tolerance to acidity of lactic acid bacteria has been associated with the induction of the activity of $\mathrm{H}^{+}$-ATPase (Guo et al. 2009). A bacterium is considered probiotic when it survives after being exposed to $\mathrm{pH} 2.0$ and 3.0 for $3 \mathrm{~h}$ (Park et al. 2006). After $3 \mathrm{~h}$ at $\mathrm{pH} 2.5, P$. acidilactici B14 showed a survival rate of $45.9 \%$.

Pediococcus acidilactici B14 showed tolerance to bile salts (Table 1). After 180 and $360 \mathrm{~min}$, there were significant differences $(\mathrm{p}<0.05)$ in the viability of the strain between the treatments (control, 0.3 and 1.0\%). At the end of the $360 \mathrm{~min}$, there was a reduction of 2 and 4 logarithmic cycles of the control for 0.3 and $1.0 \%$ bile salts, respectively. Previous studies have suggested that a common bile resistance mechanism in LAB was strongly correlated to the presence of bile salt hydrolase activity, which probably exerts a detoxification effect by catalysing the hydrolysis of glycine or taurine-conjugated bile salts into amino acid residues and unconjugated bile salts (Yin et al. 2011). The normal level of bile salts in the intestine is approximately $0.3 \%$ (Gowri and Ghosh 2010). At this concentration, $P$. acidilactici B14 showed a survival rate of 72 and $70.4 \%$ for 180 and $360 \mathrm{~min}$, respectively.

Table 1 - Cell viability of Pediococcus acidilacti B14 in different conditions of $\mathrm{pH}$ and concentrations of bile salts.

\begin{tabular}{lccccccc}
\hline Time & \multicolumn{5}{c}{ Cell viability $(\log$ CFU/mL) } \\
\cline { 2 - 7 } & \multicolumn{5}{c}{ pH conditions } & \multicolumn{4}{c}{ Concentration of bile salts $(\%)$} \\
\cline { 2 - 8 } & Control & $p H 1.3$ & $p H 2.5$ & $p H 4.0$ & Control & 0.3 & 1.0 \\
\hline 0 & $12.5 \pm 0.1^{\mathrm{A}^{*}}$ & $12.3 \pm 0.1^{\mathrm{aA}}$ & $12.2 \pm 0.3^{\mathrm{aA}}$ & $12.3 \pm 0.2^{\mathrm{aA}}$ & $10.0 \pm 0.1^{\mathrm{aA}}$ & $9.8 \pm 0.2^{\mathrm{aA}}$ & $9.8 \pm 0.2^{\mathrm{aA}}$ \\
180 & $7.9 \pm 0.1^{\mathrm{aC}}$ & $3.8 \pm 0.1^{\mathrm{dB}}$ & $5.6 \pm 0.6^{\mathrm{cB}}$ & $7.0 \pm 0.1^{\mathrm{bB}}$ & $8.0 \pm 0.1^{\mathrm{aC}}$ & $7.1 \pm 0.1^{\mathrm{bB}}$ & $4.2 \pm 0.1^{\mathrm{cC}}$ \\
360 & $10.1 \pm 0.2^{\mathrm{B}}$ & $\mathrm{NC}^{* *}$ & $\mathrm{NC}$ & $\mathrm{NC}$ & $8.9 \pm 0.1^{\mathrm{aB}}$ & $6.9 \pm 0.2^{\mathrm{bB}}$ & $4.9 \pm 0.1^{\mathrm{cB}}$ \\
\hline
\end{tabular}

*Different lowercase letters between treatments for the same times, and different uppercase letters for treatments at different times represent significant difference $(\mathrm{p}<0.05)$ (Tukey's post-test); **NC - no cell growth.

Diameters of inhibition zones were compared to interpretation standards of the Enterococcus genus (Clinical and Laboratory Standards Institute 2009) in order to evaluate the behaviour of $P$. acidilactici B14 in relation to antibiotics. The culture showed sensitivity to the following compounds: amoxicillin $(17.0 \mathrm{~mm})$, clindamycin $(24.8 \mathrm{~mm})$, chloramphenicol $(20.0 \mathrm{~mm})$, 
erythromycin $(24.8 \mathrm{~mm})$ and imipenem (29.2 $\mathrm{mm})$. The presence of tetracycline $(15.7 \mathrm{~mm})$ partially inhibited the activity of the strain and the antibiotics showed varied tolerance [cephalexin $(12.1 \mathrm{~mm})$, cefotaxime (no zone formation), neomycin $(11.4 \mathrm{~mm})$, penicillin $\mathrm{G}(24.3 \mathrm{~mm})$ and vancomycin (no zone formation)]. The resistance to vancomycin presented by the $P$. acidilactici B14 strain was inherent in the Pediococcus genus (Toomey et al. 2010). The high value of the minimum inhibitory concentration (MIC> 256.0 $\mathrm{mg} / \mathrm{L}$ ) to vancomycin was due to the known intrinsic resistance to glycopeptides of the bacteria of this genus.

Because the $P$. acidilactici B14 strain was homofermentative and a producer of lactic acid in the racemic form, it was considered that compounds such as carbon dioxide and ethanol would not be formed in its metabolic pathway. Therefore, the inhibitory activity to the tested pathogens could be due to the presence of acidity, hydrogen peroxide and possible antimicrobial compounds that were excreted (Table 2). The antagonistic effect obtained for the E. coli ATCC 25922 strain, which was a Gram-negative microorganism, appeared to be entirely dependent on acidity because there was no inhibition in the buffered medium. However, for the pathogens, Salmonella sp., B. cereus ATCC 33018 and S. aureus ATCC 6538P, the inhibition zones were reduced by $30.8,6.3$ and $7.8 \%$, respectively, when evaluated against the dependence of antagonism to acidity.

Table 2 - Antagonistic effect of Pediococcus acidilactici B14 in the presence of pathogens

\begin{tabular}{lcccc}
\hline Treatment & \multicolumn{4}{c}{ Diameter of inhibition zones (mm) } \\
\cline { 2 - 5 } & $\begin{array}{c}\text { Salmonella } \\
\text { sp. }\end{array}$ & B. cereus & E. coli & S. aureus \\
& & & 25922 & $6538 \mathrm{P}$ \\
\hline MRS agar & $27.0 \pm 1.7^{\mathrm{a}^{*}}$ & $25.3 \pm 1.1^{\mathrm{a}}$ & $16.0 \pm 0.1$ & $21.7 \pm 0.9^{\mathrm{a}}$ \\
Buffered & $18.7 \pm 0.6^{\mathrm{b}}$ & $23.7 \pm 0.6^{\mathrm{b}}$ & NI** & $20.0 \pm 0.2^{\mathrm{b}}$ \\
MRS agar & & & \\
*Different letters in the same column show differences $(\mathrm{p}<0.05)$ \\
(Tukey's post-test); **NI - no inhibition of pathogen.
\end{tabular}

The Gram-negative pathogens that were tested ( $E$. coli ATCC 25922 and Salmonella sp.) showed increased sensitivity to the inhibitory effect of the present acid. However, in the Gram-positive strains (B. cereus ATCC 33018 and S. aureus ATCC 6538P), other possible mechanisms, such as the presence of hydrogen peroxide and/or antimicrobial substances might also have been acting in the inhibition.

Servin (2004) stressed the importance of organic acids as having a strong inhibitory effect against Gram-negative bacteria, whereby the lactic acid acted as a permeator of the outer membrane of these bacteria, allowing other antimicrobial substances to penetrate and thereby increase the susceptibility of pathogens to antimicrobial molecules. Although the production of bacteriocins by $P$. acidilactici B14 was not evaluated, the results indicated the presence of other inhibitors of pathogens, such as hydrogen peroxide and bacteriocins. The pattern of adhesion of $P$. acidilactici B14 was evaluated in monolayers of the HRT-18 human colon adenocarcinoma cell strain. The adhesion capacity of $P$. acidilactici B14 for the HRT-18 strain was $0.6 \pm 0.1$ cells per adenocarcinoma cell.

Considering the similarity of origin between the Caco-2, HT-29 and HRT-18 strains, and the lack of reports on the use of the HRT-18 strain, data on the adhesion of LAB in Caco-2 cells were used for comparison. The adhesion capacity of $P$. acidilactici B14 in HRT-18 cells was considered as absent when using the standard of no adhesiveness ( $<5$ bacteria/ Caco- 2 cell) (Candela et al. 2005). However, considering the parameters proposed by Del Re et al. (2000), who evaluated the adhesive capacity of strains of B. longum and defined 'strong' as adhesive capacity over 40 bacteria/100 Caco-2 cells, then the $P$. acidilactici B14 strain showed strong adhesive capacity. Due to the absence of conclusive data regarding the pattern of adhesion of bacterial cells in intestinal epithelial cell models, it was not possible to define this property in terms of the adhesive capacity of the evaluated strain.

Adherence to mucosal surfaces by probiotic microorganisms is an important ability for the colonisation of the human gastrointestinal system, which prevents their elimination by peristalsis and provides a competitive advantage over pathogens (Rivera-Espinoza et al. 2010). Self-aggregation seems to be required for the adhesion of probiotic strains to intestinal epithelial cells and the ability to co-aggregate can form a barrier that prevents colonisation by the pathogens (Collado et al. 2008). Due to the importance of elucidating the adhesion ability of $P$. acidilactici B14 in intestinal epithelial cells, it was considered relevant to assess the properties of self-aggregation and coaggregation of this strain. Therefore, it was 
decided to use Caco-2 or HT-29 cell lines, which were most used to reassess the ability of adhesion. After being subjected to GIS simulation (Fig. 1), the cell viability of $P$. acidilactici $\mathrm{B} 14$ decreased by 3.2 and $0.4 \log$ cycles in cell viability at $\mathrm{pH} 2.0$ and 4.0 , respectively.

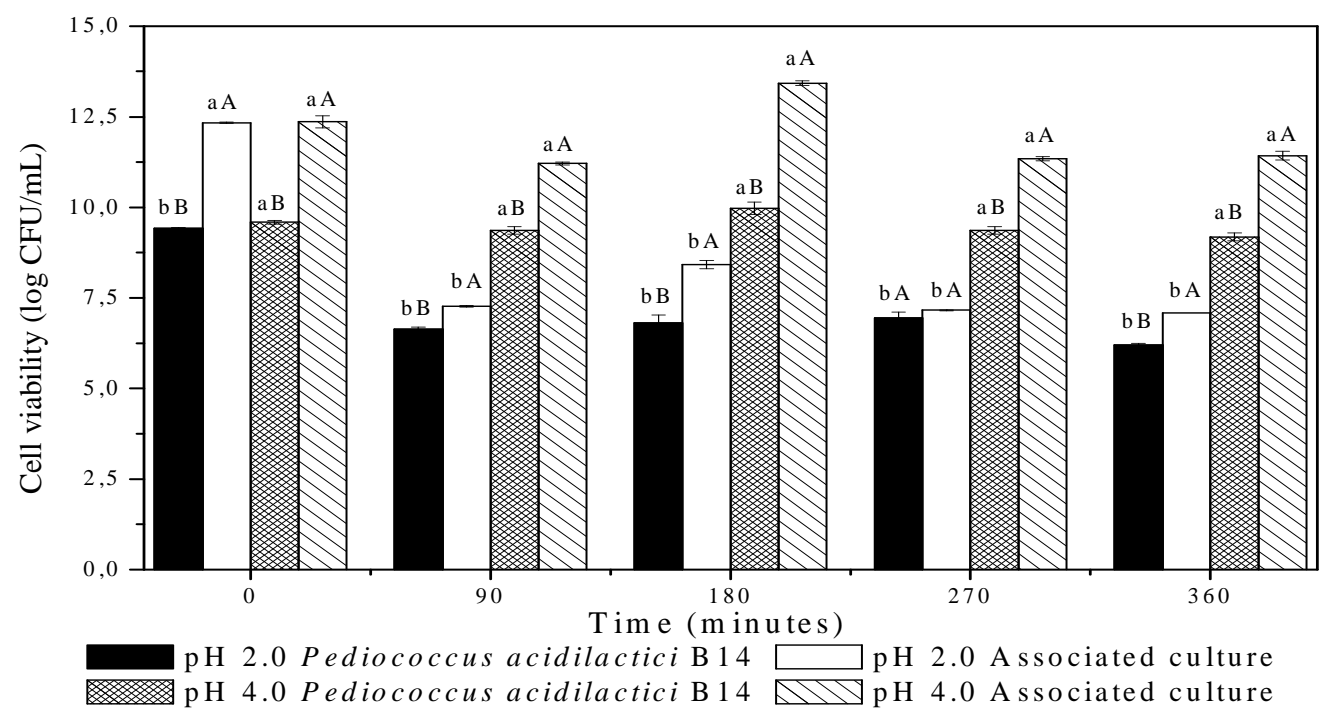

Figure 1 - Cell viability of Pediococcus acidilactici B14 and associated culture after being subjected to the gastrointestinal system.

Different lowercase letters between $\mathrm{pH}$ conditions in the same culture and time, different capital letters between the cultures at the same $\mathrm{pH}$ and time conditions, signify significant difference ( $\mathrm{p}$ $<0.05)$ (Tukey's post-test).

The analysis of the participation of GJ in cellular viability in isolation showed that at $\mathrm{pH} 2.0$ the presence of GJ reduced the population by $29.6 \%$. During the period that $P$. acidilactici B14 remained in $\mathrm{GJ}$ at $\mathrm{pH} 4.0$, the initial population decreased by $2.4 \%$. However, when this strain was

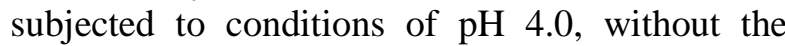
presence of pepsin (Table 1), the reduction was $43.1 \%$. This reduction in the loss of cellular viability from 43.1 to $2.4 \%$ corroborated the results obtained by Guo et al. (2009), who observed that when strains of $L b$. casei Zhang, $L b$. acidophilus NCFM, Lb. rhamnosus GG and $B$. animalis $\mathrm{Bb} 12$ were placed in contact with simulated GJ at $\mathrm{pH} 2.5,3.0$ and 4.0, the presence of pepsin improved the survival of the probiotics in the acidic conditions tested. Mättö et al. (2006) observed that the supplementation with pepsin improved the survival of the $B$. animalis subsp. lactis strain during exposure to low $\mathrm{pH}$ and this effect was not detected in five other strains of bifidobacteria found in the human gastrointestinal tract.

Pediococci are microorganisms that are still little studied; however, interest seems to be increasing, both in the scientific community and in industry. In recent years, many important studies have been published, and supplements containing Pediococcus spp. have entered the nutraceutical market (Papagianni and Anastasiadou 2009). Considering that the probiotic properties are specific to microbial strains, these results showed potential for the application of the B14 strain of $P$. acidilactici.

The mixed of $P$. acidilactici B14 with $L b$. acidophilus ATCC 4356 showed the reduced cell viability obtained after simulating the GIS by 5.3 and $0.9 \mathrm{log}$ cycles of cell viability for $\mathrm{pH}$ of 2.0 and 4.0, respectively. The decrease in viability in the mixed culture at $\mathrm{pH} 2.0$ in GJ was $41 \%$ and for the GJ at $\mathrm{pH} 4.0$, a decrease of $9.3 \%$ was observed. Comparing the resistance of $P$. acidilactici B14 individually and mixed with $L b$. acidophilus ATCC 4356, it was possible to see a significant difference $(\mathrm{p}<0.05)$ in the survival rates in GIS for GJ at $\mathrm{pH}$ of 2.0, which were 65.8 and $57.4 \%$, and for $\mathrm{pH} 4.0$, which were 95.8 and $92.4 \%$, respectively. These survival rates represented the population that remained viable after being subjected to gastrointestinal conditions 
and which could adhere to intestinal epithelial cells to operate in the establishment and/or maintenance of normobiosis. Considering the finding by Mättö et al. (2006), that the survival of probiotics during intestinal transit could be estimated at approximately $10-40 \%$ of the total administered, the survival rates obtained for $P$. acidilactici B14, both individually and mixed with Lb. acidophilus ATCC 4356, were above those recommended for probiotics.

Resistance of the Associated Culture to Gastrointestinal System in the Food Matrix

According to Bedani et al. (2013), the study of the tolerance of gastrointestinal conditions, conducted with probiotic bacteria incorporated in the final product, appears to be useful in selecting a suitable food matrix that contributes to the survival of the probiotic in the gastrointestinal tract. Consequently, to evaluate the behaviour of the associated culture in food, it was decided to develop a dessert with aerated soy, considered to be a semisolid matrix with 5.5, 3.7 and $2.5 \%$ in protein, fat and dietary fibre (results not shown) levels, respectively. The protein content was split into $45.0,36.0$ and $19.0 \%$ of soy, milk and gelatin, respectively. When subjected to GIS with GJ at pH 2.0 (Fig. 2), after $180 \mathrm{~min}$ (the total time of the gastric stage) the associated culture inserted into the food matrix presented a reduction of 2.5 and $3.2 \log$ cycles for the samples stored for 1 and 28 days, respectively.

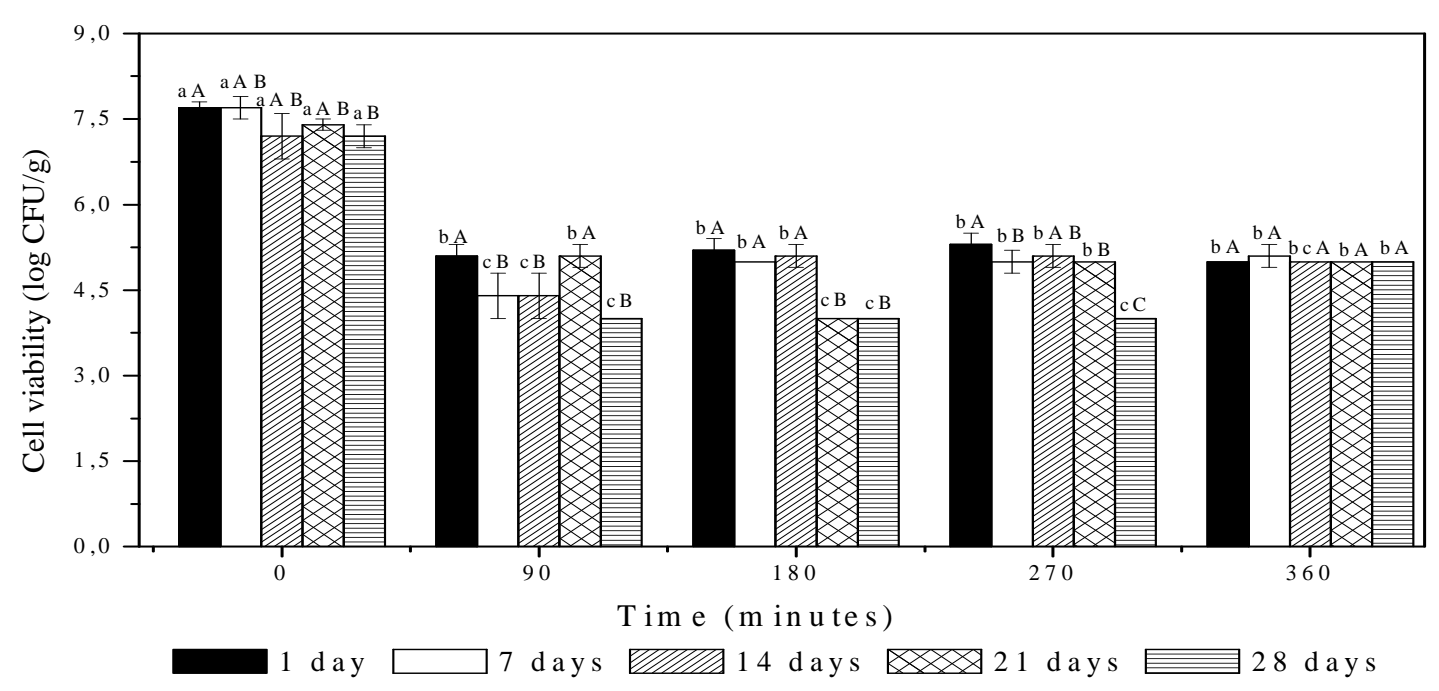

Figure 2 - Cell viability of the associated culture in the dessert, undergoing simulated GIS with GJ at pH 2.0.

Different lowercase letters between the times of simulation in GIS and different capital letters between the times of cold storage represent significant difference at 5\% (Tukey's post-test).

When the resistance of the mixed culture of $P$. acidilactici $\mathrm{B} 14$ and Lb. acidophilus ATCC 4356 was assessed for all the GIS, a cell viability reduction of $35.4,33.3,30.7,32.1$, and $30.3 \%$ was observed for the desserts stored for 1, 7, 14, 21 and 28 days, respectively. When the mixed culture was evaluated without the food matrix, it presented a reduction of $42.6 \%$ in the cell population for the same simulation conditions (Fig. 1). This indicated that in the presence of the food matrix, there was an average increase in the survival of the bacterial population of $9.9 \%$ for the tested conditions. Foods with a high fat content and the presence of certain proteins can protect bacteria from stomach acidity and thus increase the survival of gastric transit (Monteagudo-Mera et al. 2012).

When the desserts were submitted to GIS with GJ at $\mathrm{pH} 4.0$ (Fig. 3), the viability of the associated culture was higher to the GJ at pH 2.0 (Fig. 2). For the time of $180 \mathrm{~min}$, the desserts of 1,7 and 14 days storage showed no significant differences ( $p$ $<0.05$ ) for cell viability, with no observed reduction of 1 complete $\log$ cycle in all the 
analyzed samples. After the simulation of the transition to GIS, the populations of 7.4, 7.4, 7.3, 7.5 and $7.2 \log$ CFU/g for the desserts of $1,7,14$, 21 and 28 days of storage, respectively, were obtained. The resistance strength of the associated culture for all the GIS decreased by 3.9, 2.9, 0.3, 0.1 and $0.2 \%$ of the cell population for the desserts of $1,7,14,21$ and 28 days of storage, respectively. When evaluated without the food matrix, the mixed culture showed a reduction of $7.6 \%$ in the bacterial population, representing a $6.1 \%$ average increase in cell viability. Thus, as in the simulation of the GIS with IJ at $\mathrm{pH} 2.0$, it was observed that the food matrix that was used might have produced a barrier effect in the adverse simulated conditions.

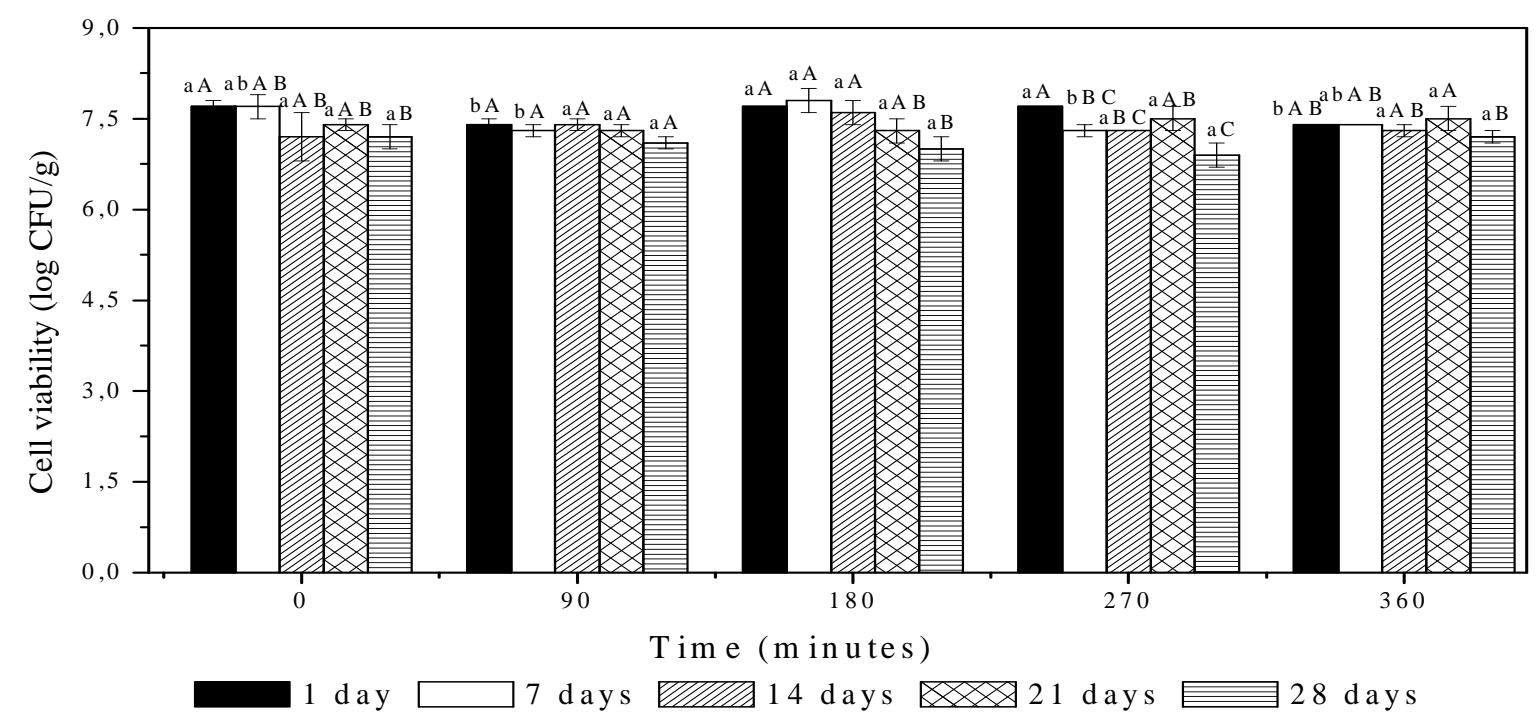

Figure 3 - Cell viability of the associated culture in desserts regarding the simulated SGI at pH 4.0. Different lowercase letters between the times of simulation of GIS and different capital letters between the times of cold storage represent significant difference at 5\% (Tukey's test).

Fructans such as inulin, which in the food matrix binds to the available water and forms a gel consisting of a network of crystalline particles, may exert a protective effect as a prebiotic food ingredient, improving the survival and activity of probiotic bacteria during the storage of probiotic food, as well as passing through the GIS (Buriti et al. 2010). Other ingredients such as whey protein concentrate may have a similar protective effect, increasing conservation during shelf life and resistance against changes in $\mathrm{pH}$ and enzymes secreted during the transition to GIS (Akalin et al. 2007). The results obtained in this study regarding the maintenance of the population of probiotic microorganisms were closely related to the chemical composition and physical structure of the food matrix chosen as a protective barrier during gastrointestinal transit. Due to its composition, which is rich in compounds capable of forming the protective structures as fats, proteins and fructooligosaccharides, and its semisolid physical characteristics, the dessert with aerated soybean could be considered as an interesting food matrix to be studied in the functional food market. The association between $P$. acidilactici B14 and Lb. acidophilus ATCC 4356 was performed with the aim of enhancing the probiotic properties of both cultures. Thus, because the selected food matrix caused an average increase of $8.0 \%$ in cell viability, the application of this mixed culture could be considered advantageous from the aspect of the product's functionality.

\section{CONCLUSIONS}

Pediococcus acidilactici B14 showed potential regarding the probiotic properties such as antagonism to pathogens; survival rates of $45.9 \%$ at $\mathrm{pH} 2.5$ and $72.4 \%$ in $0.3 \%$ bile salts during a time of $3 \mathrm{~h}$ and 
survival rates after GIS simulation of $65.8 \%$ at $\mathrm{pH} 2.0$ and $95.8 \%$ at $\mathrm{pH} 4.0$, respectively. Compared to the $P$. acidilactici B14 individually, the mixed culture showed a reduction in survival rates of 8.4 and $3.4 \%$ after remaining in GIS at $\mathrm{pH} 2.0$ and 4.0, respectively. However, in the presence of the food matrix, there was an average increase in cell viability after being subjected to GIS at $\mathrm{pH} 2.0$ of $9.9 \%$ and $6.1 \%$ at $\mathrm{pH} 4.0$.

\section{ACKNOWLEDGEMENTS}

The authors would like to thank CAPES and $\mathrm{CNPq}$ for financial support.

\section{REFERENCES}

Ahmadova A, Todorov SD, Choiset Y, Rabesona H, Zadi TM, Kuliyev A, et al. Evaluation of antimicrobial activity, probiotic properties and safety of wild strain Enterococcus faecium AQ71 isolated from Azerbaijani Motal cheese. Food Control. 2013; 30: 631-641.

Akalin A S, Gönç S, Ünal G, Fenderya S. Effects of frutooligosaccharide and whey protein concentrate on the viability of starter culture in reduced probiotic yogurt during storage. J Food Sci. 2007; 72: M222227.

Albano H, Pinho C, Leite D, Barbosa J, Silva J, Carneiro L, et al. Evaluation of a bacteriocinproducing strain of Pediococcus acidilactici as a biopreservative for "Alheira" a fermented meat sausage. Food Control. 2009; 20:764-770.

Araújo TF, Ferreira CLLF. The genus Enterococcus as probiotic: safety concerns. Braz Arch Biol Technol. 2013; 56: 457-466.

Baumgartner A, Kueffer M, Simmen A, Grand M. Relatedness of L. rhamnosus strains isolated from clinical specimens and such from food-stuffs humans and technology. Lebensm-Wiss Technol. 1998; 31: 489-494.

Bedani R, Rossi E A, Saad S M I. Impact of inulin and okara on Lactobacillus acidophilus La-5 and Bifidobacterium animalis $\mathrm{Bb}-12$ viability in a fermented soy product and probiotic survival under in vitro simulated gastrointestinal conditions. Food Microbiol. 2013; 34: 382-389.

Buriti FCA, Castro IA, Saad SMI. Viability of Lactobacillus acidophilus in synbiotic guava mousses and its survival under in vitro simulated gastrointestinal conditions. Int J Food Microbiology. 2010; 137: 121-129.
Campana R, Federici S, Ciandrini E, Baffone W. Antagonistic activity of Lactobacillus acidophilus ATCC 4356 on the growth and adhesion/invasion characteristics of human Campylobacter jejuni. Curr Microbiol. 2012; 64: 371-378.

Candela M, Seibold G, Vitali B, Lanchenmaier S, Eikmanns BJ, Brigidi P. Real-time PCR quantification of bacterial adhesion to Caco-2 cells: competition between bifidobacteria and enteropathogens. Res Microb. 2005; 156: 887-895.

Carvalho HAS, Ribeiro LF, Pirovani CP, Gramacho $\mathrm{KP}$, Micheli F. Activity of polygalacturonases from Moniliophthora perniciosa depends on fungus culture conditions and is enhanced by Theobroma cacao extracts. Physiol Mol Plant P. 2013; 83: 4050.

Clinical and Laboratory Standards Institute (CLSI). Performance standards for antimicrobial disk susceptibility tests approved standard: document M2A8. $8^{\text {th }}$ ed. Wayne: CLSI; 2003 [cited 2011 oct. 16]. Available from: http://www.clsi.org/source/ orders/free/m2-a8.pdf

Clinical and Laboratory Standards Institutes (CLSI). Methods for dilution antimicrobial susceptibility tests for bacteria that grow aerobically approved standard: document M07-A8. $8^{\text {th }}$ ed. Wayne: CLSI; 2009 [cited 2012 jan.25]. Available from: http://www.clsi.org/source/orders/free/m07-a8.pdf

Collado MC, Meriluoto J, Salminen S. Adhesion and aggregation properties of probiotic and pathogen strains. Eur Food Res Technol. 2008; 226: $1065-$ 1073.

Da Silva N, Junqueira VCA, Silveira NFA, Taniwaki MH, Dos Santos RFS, Gomes RAR. Manual de métodos de análise microbiológica de alimentos e água. $4^{\text {th }}$ ed. São Paulo: Varela; 2010.

Darilmaz DO, Ashm B, Suludere Z, Akca G. Influence of gastrointestinal system conditions on adhesion of exopolysaccharide-producing Lactobacillus delbrueckii subsp. bulgaricus strains to Caco-2 Cells. Braz Arch Biol Technol. 2011; 54: 917-926.

Del Re B, Sgorbati B, Miglioli M, Palezona D. Adhesion, autoaggregation and hydrophobicity of 13 strains of Bifidobacterium longum. Lett Appl Microbiol. 2000; 31: 438-442.

Fernández MF, Boris S, Barbés C. Probiotic properties of human lactobacilli strains to be used in the gastrointestinal tract. J Appl Microbiol. 2003; 94: 449-455.

Gowri S, Ghosh AR. Pediococcus spp. - a potential probiotic isolated from Khadi (an Indian fermented food) and identified by $16 \mathrm{~S}$ rDNA sequences analysis. Afr J Food Sci. 2010; 4: 597-602. 
Guo Z, Wang J, Yan L, Chen W, Liu XM, Zhang HP. In vitro comparison of probiotic properties of Lactobacillus casei Zhang a potential new probiotic, with selected probiotic strains. LWT- Food Sci Technol. 2009; 42: 1640-1646.

Haakensen M, Vickers DM, Ziola B. Susceptibility of Pediococcus isolates to antimicrobial compounds in relation to hop-resistance and beer-spoilage. $B M C$ Microbiol. 2009; 9: 1-7.

Huang Y, Zheng Y. The probiotic Lactobacillus acidophilus ATCC 4356 reduces cholesterol absorption through the down-regulation of NiemannPick C1-like in Caco-2 cells. Br J Nutr. 2010; 103: 473-478.

Klare I, Konstabel C, Werner G, Huy SG, Vankerckhoven V, Kahlmeter G, et al. Antimicrobial susceptibilities of Lactobacillus, Pediococcus and Lactococcus human isolates and cultures intended for probiotic or nutritional use. J Antimicrob Chemoth. 2007; 59: 900-912.

Mättö J, Alakomi HL, Virkajärvi AVI, Saarela M. Influence of processing conditions on Bifidobacterium animalis subsp. lactis functionality with a special focus on acid tolerance and factors affecting it. Int Dairy J. 2006; 16: 1029-1037.

Monteagudo-Mera A, Rodríguez-Aparicio L, Rúa J, Martínez-Blanco H, Navasa N, García-Armesto MR, et al. In vitro evaluation of physiological probiotic properties of different lactic acid bacteria strains of dairy and human origin. J Funct Foods. 2012; 4: 531-541.

Papagianni M, Anastasiadou S. Encapsulation of Pediococcus acidilactici cells in corn and olive oil microcapsules emulsified by peptides and stabilized with xanthan in oil-in-water emulsions: studies on cell viability under gastro-intestinal simulating conditions. Enzyme Microb Tech. 2009; 45: 514-522.

Park SC, Hwang MH, Kim2 YH, Kim JC, Song JC, Lee $\mathrm{KW}$, et al. Comparison of $\mathrm{pH}$ and bile resistance of Lactobacillus acidophilus strains isolated from rat, pig, chicken, and human sources. World J Microb Biot. 2006; 22: 35-37.
Rivera-Espinoza Y, Gallardo-Navarro Y. Non-dairy probiotic products. Food Microbiol. 2010; 27: 1-11.

Servin AL. Antagonistic activities of lactobacilli and bifidobacteria against microbial pathogens. FEMS Microbiol Rev. 2004; 28: 405-440.

Soccol CR, Vandenberghe LPS, Spier MR, Medeiros ABP, Yamaguishi CT, Lindner JDD, et al. The potential of probiotics: a review. Food Technol and Biotechnol. 2010; 48: 413-434.

Su YA, Sulavik MC, He P, Makinen KK, Makinen PL, Fiedler $\mathrm{S}$, et al. Nucleotide sequence of the gelatinase gene (geIE) from Enterococcus faecalis subsp. liquefaciens. Infect Immun. 1991; 59: 415-420.

Toomey N, Bolton D, Fanning S. Characterisation and transferability of antibiotic resistance genes from lactic acid bacteria isolated from Irish pork and beef abattoirs. Res Microbiol. 2010; 161: 127-135.

Tulini FL, Winkelströter LK, De Martinis ECP. Identification and evaluation of the probiotic potential of Lactobacillus paraplantarum FT259, a bacteriocinogenic strain isolated from Brazilian semi-hard artisanal cheese. Anaerobe. 2013; 22: 5763.

Vinderola G, Zacarias MF, Bockelmann W, Neve H, Reinheimer J, Heller KJ. Preservation of functionality of Bifidobacterium animalis subsp. lactis INL1 after incorporation of freeze-dried cells into different food matrices. Food Microbiol. 2012; 30: 274-280.

Yin S, Zhai Z, Wang G, Na H, Luo Y, Hao Y. A novel vector for lactic acid bacteria that uses a bile salt hydrolase gene as a potential food-grade selection marker. J Biotechnol. 2011; 152: 49-53.

Received: August 08, 2013; Accepted: December 23, 2013. 